\title{
Deskripsi Materi-materi Biologi yang Diminati dan Tidak Diminati oleh Mahasiswa Program Studi Pendidikan Biologi
}

\author{
Reni Marlina \\ Pendidikan Biologi. FKIP Universitas Tanjungpura
}

\begin{abstract}
Abstrak
Penelitian ini bertujuan untuk memperoleh informasi tentang minat mahasiswa semester awal tahun ajaran 20092010 pada materi biologi di program studi pendidikan biologi. Metode penelitian yang digunakan adalah metode deskriptif. Sampel berjumlah 30 mahasiswa yang berasal dari lima kabupaten dan satu kotamadya di Kalimantan Barat yaitu kabupaten Pontianak, Kubu Raya, Sintang, Sanggau, Singkawang. dan Kotamadya Pontianak. Instrumen penelitian yang digunakan berupa instrumen skala minat. Secara khusus penelitian ini menghasilkan hal-hal sebagai berikut: (1) sebagian besar $(56.8 \%)$ materi biologi yang terdapat dalam KTSP sangat diminati oleh mahasiswa; (2) minat mahasiswa pada materi biologi berada dalam kategori cukup berminat.
\end{abstract}

Kata kunci: materi biologi, minat mahasiswa

\section{Pendahuluan}

Salah satu karakteristik pada ranah afektif adalah minat peserta didik. Minat adalah suatu rasa lebih suka dan rasa ketertarikan pada suatu hal atau aktifitas, tanpa ada yang menyuruh (Slameto, 2010). Menurut Getzel (1966) dalam Depdiknas (2008), minat adalah suatu disposisi yang terorganisir melalui pengalaman yang mendorong seseorang untuk memperoleh objek khusus, aktivitas, pemahaman, dan keterampilan untuk tujuan perhatian atau pencapaian. Sedangkan menurut Kamus Besar Bahasa Indonesia (1990: 583), minat atau keinginan adalah kecenderungan hati yang tinggi terhadap sesuatu. Sesuatu itu dapat berupa orang, benda, kegiatan, pengalaman dan lain-lain yang dapat dijadikan sebagai stimulus yang memerlukan respon terarah (Arifin, 2012: 241).
Minat merupakan salah satu faktor yang dapat mempengaruhi proses dan hasil belajar sehingga perlu diperhatikan faktor-faktor yang dapat mempengaruhi munculnya minat seperti motivasi, belajar, materi pelajaran, keluarga, teman, cita-cita dan lain-lain (Arifin, 2012: 241). Bila dicermati, minat sangat erat kaitannya dengan kebutuhan seseorang. Artinya jika minat yang muncul sesuai dengan kebutuhan maka dapat menjadi faktor pendorong dalam melakukan suatu tindakan. Sebaliknya jika minat tidak sesuai dengan kebutuhan maka hal tersebut akan ditinggalkan. Hal ini sesuai dengan apa yang dikemukakan oleh Djamarah (2005) bahwa minat timbul bersangkut paut dengan masalah kebutuhan, karena itu dosen memberikan motivasi dengan memanfaatkan kebutuhan mahasiswa agar dia berminat untuk belajar. Bila mahasiswa berminat pada suatu mata 
kuliah, dia akan memperhatikannya dalam jangka waktu tertentu. Sehingga minat sangat berhubungan dengan sikap. Dalam proses pembelajaran sering terjadi jika mahasiswa berminat terhadap materi pelajaran, maka sikap mahasiswa cenderung memperhatikan pelajaran tersebut.

Isu mengenai minat dan sikap mahasiswa dalam memilih jurusan sains khususnya IPA seringkali muncul dari kalangan pendidik IPA. Hal ini berkaitan dengan pencapaian nilai kognitif terutama pada mata pelajaran karakteristik IPA. Berdasarkan pedoman penjurusan program studi tentang penentuan dan penjurusan mahasiswa pada program studi IPA, dijelaskan bahwa mahasiswa dapat mengambil program IPA jika telah memenuhi persyaratan nilai akademis. Kondisi ini dipandang 'kurang adil' karena di dalamnya kurang mengakomodasi pandangan dan nilai yang dianut mahasiswa sebagai target utama dari pendidikan IPA. Akibatnya minat mahasiswa seringkali diabaikan hanya karena nilai kognitif yang mereka peroleh.

Salah satu pelajaran IPA adalah pelajaran biologi. Menurut Ekli, et al., (2009), pelajaran biologi merupakan pelajaran yang membosankan dan harus dipelajari dengan kesungguhan hati. Dalam studi biologi sering dan banyak digunakan istilah-istilah yang pada umumnya berupa istilah Latin atau kata yang dilatinkan. Banyaknya istilah Latin tersebut menyebabkan kurangnya minat para mahasiswa untuk memasuki jurusan biologi dan jurusan-jurusan yang menggunakan biologi sebagai ilmu dasarnya (Rustaman, 2005). Rendahnya pencapaian hasil belajar biologi memerlukan analisis komprehensif dengan cara memahami apa yang menjadi minat dan bagaimana mahasiswa memaknai mata pelajaran biologi.

\section{Metode Penelitian}

Penelitian ini bertujuan untuk mendeskripsikan materi-materi biologi yang diminati dan yang tidak diminati oleh mahasiswa semester awal. Metode penelitian yang digunakan adalah metode deskriptif. Berdasarkan hasil penelitian akan digambarkan minat mahasiswa yang meliputi materi yang sangat diminati. materi yang tidak diminati, ketertarikan pada materi biologi. kesulitan pelajaran biologi. dan pentingnya biologi. Subjek dalam penelitian ini adalah mahasiswa program studi pendidikan Biologi jurusan Pendidikan MIPA FKIP Untan yang berjumlah 30 orang. Mahasiswa yang terlibat dalam pengambilan data adalah berasal dari beberapa kabupaten di kalimantan barat. Objek dalam penelitian ini adalah materi-materi biologi yang diminati dan yang tidak diminati oleh mahasiswa. Pada penelitian ini, peneliti menggunakan instrumen skala minat untuk menjaring minat siswa terhadap materi biologi.

Kegiatan yang dilakukan pada penelitian ini meliputi tiga tahapan, yaitu: tahap persiapan, tahap pelaksanaan, dan tahap akhir.

Tahap Persiapan

a. Melakukan kajian literatur dan studi kasus untuk menentukan masalah yang akan diangkat dalam penelitian.

b. Melakukan analisis kurikulum untuk mengetahui topik apa saja 
yang terdapat dalam pelajaran biologi.

c. Melakukan analisis jurnal internasional yang berkaitan dengan minat mahasiswa untuk mengetahui indikatorindikatornya sehingga dapat dijadikan rujukan dalam pembuatan instrumen.

d. Menyusun kisi-kisi instrumen skala minat mahasiswa.

e. Setelah instrumen tersusun kemudian dilakukan penilaian (judgement) dan revisi, kemudian dilakukan uji coba instrumen sampai instrumen siap untuk digunakan.

2. Tahap Pelaksanaan

Penelitian ini dilakukan pada semester genap tahun ajaran 2009/2010. Penelitian dilakukan dalam dua kegiatan. Kegiatan pertama dilakukan untuk penyebaran instrumen yang telah diuji coba. Instrumen kemudian disebarkan pada mahasiswa semester awal. Kegiatan kedua dilakukan untuk melakukan kegiatan observasi pembelajaran biologi yang berlangsung di kelas yang sama.

3. Tahap Akhir

Tahapan akhir pada penelitian ini akan dilakukan analisis dan interpretasi data untuk mendeskripsikan minat mahasiswa pada materi biologi. Data yang telah diperoleh akan diklasifikasikan dan dianalisis dengan cara menghitung persentase kecocokannya berdasarkan kategori yang dikemukakan oleh Riduwan (2005), dengan rumus:

$\%$ kecocokan $\frac{\sum \text { skor indikator yang cocok }}{\sum \text { total indikator }} \times 100 \%$
Selanjutnya hasil persentase uji kecocokan diinterpretasikan berdasarkan Riduwan (2005):

$0 \leq X \leq 20 \quad$ : Sangat tidak berminat

$21 \leq X \leq 40 \quad$ : Tidak berminat

$41 \leq X \leq 60 \quad$ : Ckup berminat

$61 \leq \mathrm{X} \leq 80 \quad$ : Berminat

$81 \leq X \leq 100$ : Sangat berminat

\section{HASIL DAN PEMBAHASAN Hasil}

Untuk indikator ketertarikan mahasiswa terhadap materi biologi, merupakan minat mahasiswa pada materi biologi. Setiap pernyataan terdiri atas 4 alternatif jawaban yang selanjutnya dikelompokkan menjadi dua, yaitu kelompok materi yang sangat diminati (dengan alternatif jawaban sangat berminat dan berminat) dan kelompok materi yang sangat tidak diminati (dengan alternatif jawaban tidak berminat dan sangat tidak berminat). Untuk kelompok materi biologi yang sangat diminati nilai skor terbesar yang diperoleh adalah $46.6 \%$ dan skor terendah adalah $24.4 \%$. Materi biologi yang sangat diminati oleh mahasiswa disajikan dalam Tabel 1 .

Berdasarkan Tabel 1 dari 21 materi yang sangat diminati oleh mahasiswa pada umumnya $(85.7 \%$ atau 18 materi) merupakan materi yang memiliki karakteristik konsep yang konkrit, hanya sebagian kecil (14.3\% atau tiga materi) yang memiliki karakteristik konsep yang abstrak yaitu materi virus, fungsi enzim dan konsep gen, DNA, kromosom dan proses sintesis protein.

Untuk kelompok materi yang sangat tidak diminati oleh mahasiswa, nilai skor terbesar yang diperoleh adalah sebesar $25.6 \%$ dan skor terendah adalah $1.95 \%$. Materi yang 
sangat tidak diminati oleh mahasiswa disajikan dalam Tabel 2.

\section{Tabel 1. Materi-Materi Yang Sangat Diminati Oleh Mahasiswa}

\begin{tabular}{|c|c|c|}
\hline No & $\begin{array}{l}\sum \\
\text { Skor } \\
(\%)\end{array}$ & Materi \\
\hline 1 & 46.6 & Ruang lingkup Biologi \\
\hline 2 & 41.8 & $\begin{array}{l}\text { Objek dan permasalahan biologi } \\
\text { pada berbagai tingkat organisasi } \\
\text { kehidupan (molekul. sel. } \\
\text { jaringan. organ. individu. } \\
\text { populasi. ekosistem. dan bioma) }\end{array}$ \\
\hline 3 & 40.1 & $\begin{array}{l}\text { Virus dan peranannya bagi } \\
\text { kehidupan }\end{array}$ \\
\hline 4 & 41.5 & $\begin{array}{l}\text { Bakteri dan peranannya bagi } \\
\text { kehidupan }\end{array}$ \\
\hline 5 & 37.7 & $\begin{array}{l}\text { Jamur dan peranannya bagi } \\
\text { kehidupan }\end{array}$ \\
\hline 6 & 43.3 & $\begin{array}{c}\text { Keanekaragaman gen. jenis dan } \\
\text { ekosistem }\end{array}$ \\
\hline 7 & 48.1 & $\begin{array}{c}\text { Keanekaragaman hayati } \\
\text { Indonesia. usaha pelestarian serta } \\
\text { pemanfaatan sumber daya alam }\end{array}$ \\
\hline 8 & 44.2 & $\begin{array}{c}\text { Dunia Tumbuhan dan } \\
\text { peranannya bagi kelangsungan } \\
\text { hidup di bumi }\end{array}$ \\
\hline 9 & 41.5 & $\begin{array}{c}\text { Dunia Hewan dan peranannya } \\
\text { bagi kehidupan }\end{array}$ \\
\hline 10 & 40.1 & $\begin{array}{c}\text { Kegiatan manusia dengan } \\
\text { masalah kerusakan/pencemaran } \\
\text { lingkungan dan pelestarian } \\
\text { lingkungan }\end{array}$ \\
\hline 11 & 41.5 & $\begin{array}{l}\text { Struktur dan fungsi jaringan } \\
\text { tumbuhan }\end{array}$ \\
\hline 12 & 45.9 & Sistem gerak pada manusia \\
\hline 13 & 44.9 & Sistem peredaran darah manusia \\
\hline 14 & 44.7 & $\begin{array}{c}\text { Sistem pencernaan makanan pada } \\
\text { manusia dan hewan }\end{array}$ \\
\hline 15 & 43.9 & $\begin{array}{l}\text { Sistem pernapasan pada manusia } \\
\text { dan hewan }\end{array}$ \\
\hline 16 & 36.7 & $\begin{array}{c}\text { Sistem ekskresi pada manusia } \\
\text { dan hewan }\end{array}$ \\
\hline 17 & 41.5 & $\begin{array}{c}\text { Sistem reproduksi manusia } \\
\text { (pembentukan sel kelamin. } \\
\text { ovulasi. menstruasi. fertilisasi. } \\
\text { kehamilan, dan pemberian ASI) }\end{array}$ \\
\hline 18 & 43.2 & $\begin{array}{c}\begin{array}{c}\text { Pertumbuhan dan perkembangan } \\
\text { tumbuhan }\end{array} \\
\text {. }\end{array}$ \\
\hline 19 & 38.4 & $\begin{array}{c}\text { Fungsi enzim dalam proses } \\
\text { metabolism }\end{array}$ \\
\hline 20 & 37.9 & $\begin{array}{l}\text { Konsep gen, DNA. kromosom. } \\
\text { dan proses sintesis protein }\end{array}$ \\
\hline 21 & 41.3 & Bioteknologi \\
\hline
\end{tabular}

Keterangan :

Jumlah skor $36.6 \%-47.7 \%$ : materi yang sangat diminati

Jumlah skor $24.4 \%-35.5 \%$ : materi yang diminati

Tabel 2. Materi-Materi Yang Sangat Tidak Diminati Oleh Mahasiswa

\begin{tabular}{|c|c|c|}
\hline No & $\begin{array}{c}\text { Jumlah } \\
\text { Skor }(\%)\end{array}$ & Materi \\
\hline 1 & 15.9 & $\begin{array}{l}\text { Protista dan peranannya bagi } \\
\text { kehidupan }\end{array}$ \\
\hline 2 & 22.7 & $\begin{array}{l}\text { Peran komponen ekosistem } \\
\text { dalam aliran energi dan daur } \\
\text { biogeokimia serta } \\
\text { pemanfaatan komponen } \\
\text { ekosistem bagi kehidupan }\end{array}$ \\
\hline 3 & 16.4 & $\begin{array}{l}\text { Limbah dan daur ulang } \\
\text { limbah }\end{array}$ \\
\hline 4 & 14.5 & $\begin{array}{l}\text { Membuat produk daur ulang } \\
\text { limbah }\end{array}$ \\
\hline 5 & 18.4 & $\begin{array}{l}\text { Komponen kimiawi sel. } \\
\text { struktur dan fungsi sel } \\
\text { sebagai unit terkecil } \\
\text { kehidupan }\end{array}$ \\
\hline 6 & 21 & $\begin{array}{c}\text { Organela sel tumbuhan dan } \\
\text { hewan }\end{array}$ \\
\hline 7 & 25.6 & $\begin{array}{c}\text { Mekanisme transpor melalui } \\
\text { membran (difusi. osmosis. } \\
\text { transpor aktif. endositosis. } \\
\text { eksositosis) }\end{array}$ \\
\hline 8 & 17.4 & Kultur jaringan \\
\hline 9 & 15 & $\begin{array}{c}\text { Struktur dan fungsi jaringan } \\
\text { hewan Vertebrata }\end{array}$ \\
\hline 10 & 15.7 & $\begin{array}{c}\text { Sistem regulasi manusia } \\
\text { (saraf. endokrin dan } \\
\text { penginderaan) }\end{array}$ \\
\hline 11 & 15 & $\begin{array}{l}\text { Proses Metabolisme } \\
\text { (katabolisme dan anabolisme } \\
\text { karbohidrat) }\end{array}$ \\
\hline 12 & 18.1 & $\begin{array}{l}\text { Pembelahan sel (mitosis dan } \\
\text { meiosis) dan pewarisan sifat }\end{array}$ \\
\hline 13 & 21 & $\begin{array}{c}\text { Menerapkan prinsip hereditas } \\
\text { dalam mekanisme pewarisan } \\
\text { sifat }\end{array}$ \\
\hline 14 & 22.9 & Peristiwa mutasi \\
\hline 15 & 15.9 & $\begin{array}{c}\text { Teori. prinsip. dan } \\
\text { mekanisme evolusi biologi }\end{array}$ \\
\hline
\end{tabular}

Keterangan

Jumlah skor $13.8 \%-25.26 \%$ : materi yang sangat tidak diminati

Jumlah skor $1.95 \%-13.7 \%$ : materi yang tidak diminati 
Berdasarkan Tabel 2, dari 15 materi yang sangat tidak diminati oleh mahasiswa pada umumnya $(83.33 \%$ atau 13 materi) merupakan materi yang memiliki karakteristik konsep yang abstrak. hanya sebagian kecil materi ( $11.11 \%$ atau dua materi) yang memiliki karakteristik konsep yang konkrit yaitu struktur dan fungsi jaringan hewan vertebrata. limbah dan daur ulang limbah dan satu $(5.56 \%)$ materi aplikasi yang menghasilkan produk yaitu materi membuat produk daur ulang limbah.

a. Ketertarikan Mahasiswa Pada Pelajaran Biologi

Ketertarikan mahasiswa pada pelajaran biologi dapat dilihat pada Gambar 1.

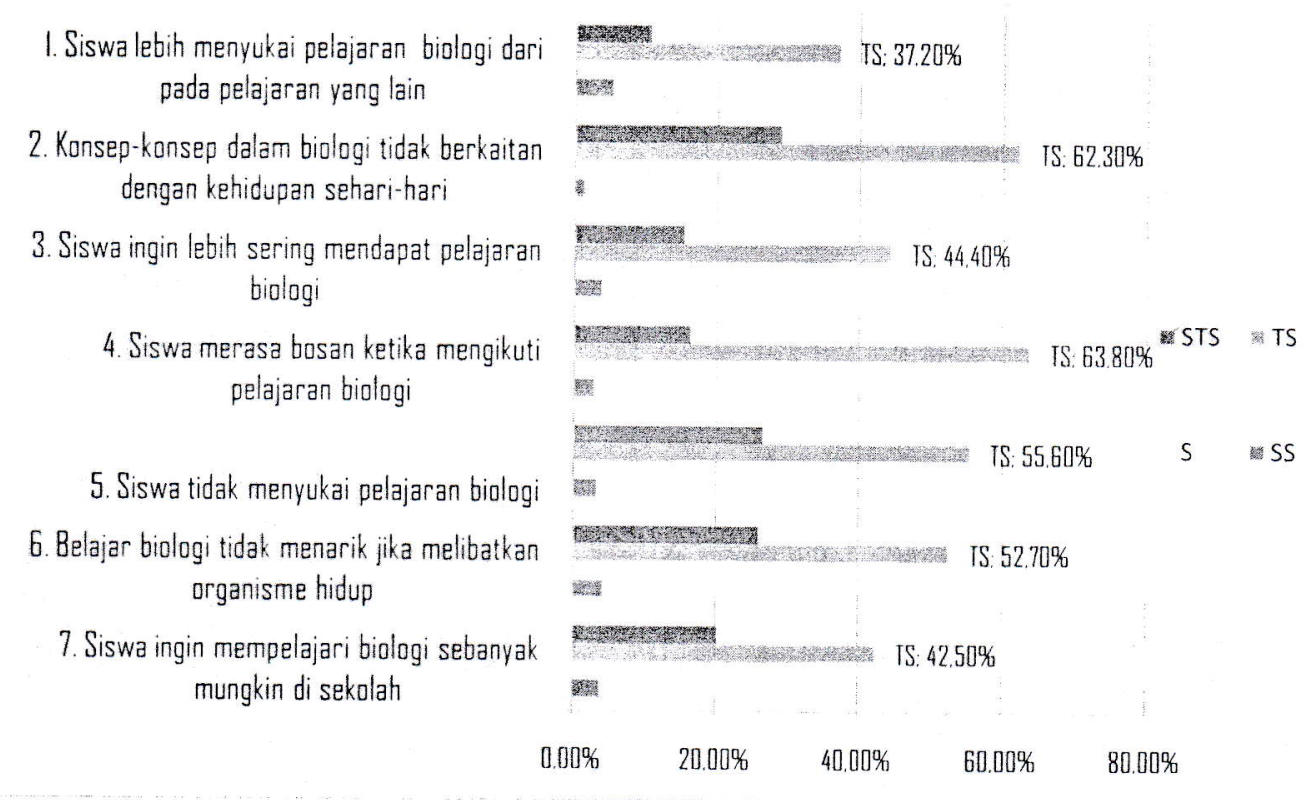

Gambar 1. Ketertarikan Mahasiswa Pada Pelajaran Biologi

Keterangan :SS : Sangat Setuju

$$
\begin{aligned}
\text { S } & : \text { Setuju } \\
\text { TS } & : \text { Tidak Setuju } \\
\text { STS } & : \text { Sangat Tidak Setuju }
\end{aligned}
$$

Berdasarkan Gambar 1, sebagian besar mahasiswa (63.8\%) tidak setuju dengan pernyataan merasa bosan ketika mengikuti pelajaran biologi. Sebagian besar mahasiswa $\quad(52.7 \% \quad-\quad 62.3 \%)$ menyatakan konsep-konsep dalam biologi berkaitan dengan kehidupan sehari-hari, menyukai pelajaran biologi dan berpendapat bahwa belajar biologi menjadi menarik jika melibatkan organisme hidup.

Hampir sebagian mahasiswa $(46.9 \%)$ lebih menyukai pelajaran biologi dari pada pelajaran yang lain. tetapi hampir sebagian mahasiswa $(44.4 \%)$ tidak ingin lebih sering mendapat pelajaran biologi. Berdasarkan informasi yang diperoleh maka kita dapat melihat bahwa lebih dari sebagian mahasiswa menyukai 
pelajaran biologi karena berkaitan dengan kehidupan sehari-hari, namun hampir separuh mahasiswa tidak ingin mendapatkan pelajaran biologi lebih sering.

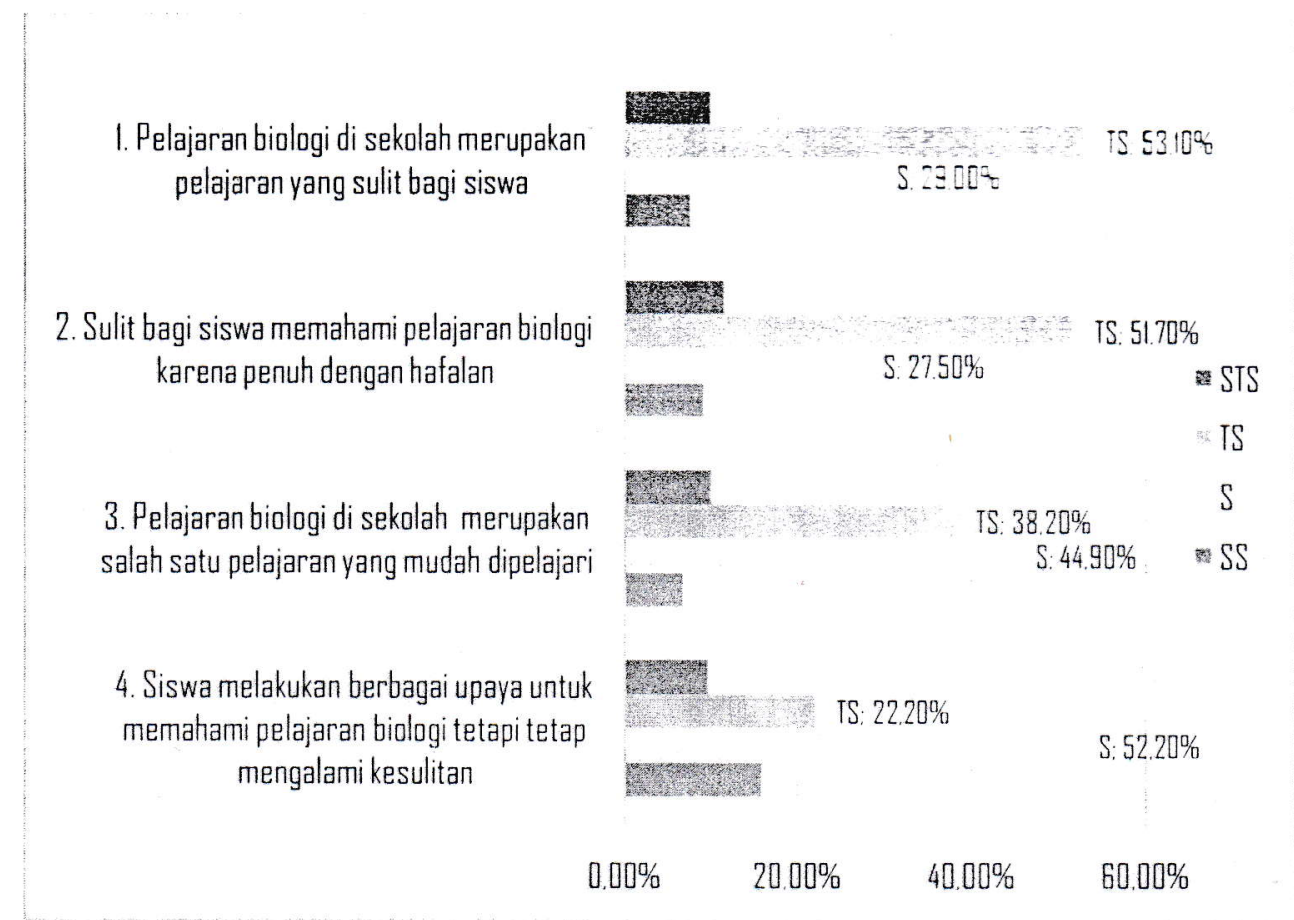

Gambar 2. Sebaran Jawaban Responden Tentang Kesulitan Pelajaran Biolog

\section{b. Kesulitan Pelajaran Biologi Pendapat mahasiswa tentang sulit atau tidak sulitnya pelajaran} biologi dapat dilihat pada Gambar 2 .

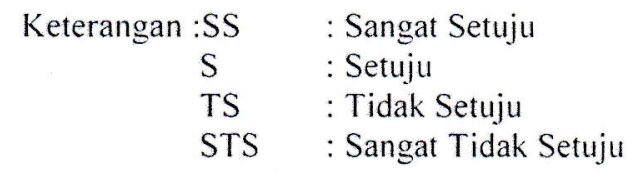

Berdasarkan Gambar 2, mengalami kesulitan dalam diperoleh informasi bahwa secara memahami pelajaran biologi umum sebagian besar mahasiswa walaupun telah melakukan berbagai menganggap pelajaran biologi mudah dipelajari. Sebagian besar mahasiswa $(51.7 \%-53.1 \%)$ tidak setuju bahwa pelajaran biologi merupakan pelajaran yang sulit dan tidak setuju dengan pernyataan sulit memahami biologi karena penuh dengan hafalan.

Hampir sebagian mahasiswa $(44.9 \%)$ setuju bahwa pelajaran biologi mudah dipelajari, namun sebagian besar mahasiswa $(52.2 \%)$ upaya.

c. Minat Mahasiswa Tentang Pentingnya Biologi

Pendapat mahasiswa tentang penting atau tidak pentingnya pelajaran biologi dapat dilihat pada Gambar 3. 
1. Hal-hal yang siswa pelajari melalui pelajaran biologi tidak dapat membantu kehidupan siswa sehari-hari

2.Pelajaran biologi telah menjadikan siswa lebih kritis dan tidak mudah percaya begitu saja (skeptis)

3. Menurut siswa semua siswa sebaiknya mempelajari biologi di sekolah

2. 数

Wesere IS: $60.40 \%$

4. Pelajaran biologi merupakan pelajaran yang tidak penting dibandingkan dengan pelajaran lain

5. Pelajaran biologi merupakan pelajaran yang tidak penting untuk memahami pelajaran lain dan fennmena yang terjadi di alam

6. Kemajuan biologi tidak dapat meningkatkan kualitas hidup kita
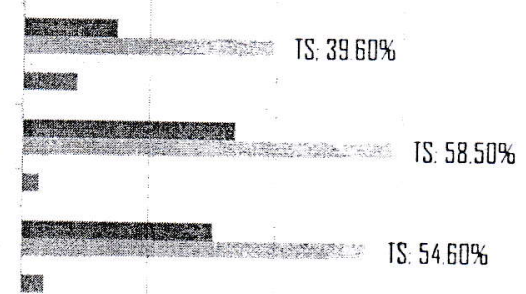

\section{rax}

TS: $54.60 \%$

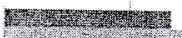

7. Biologi bukan merupakan harapan kita untuk memecahkan masalah lingkungan

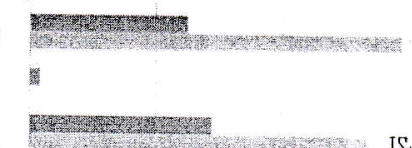

8. Bialogi bukan bagian penting dalam hidup kita

9. Tidak semua arang membutuhkan pelajaran biologi

10. Pelajaran biologi telah membangkitkan rasa ingin tahu siswa tentang sesuatu yang belum diketahui

II. Pelajaran biologi tidak membangkitkan apresiasi dan kepedulian terhadap alam sekitar

12. Pelajaran biologi tidak memperlihatkan kepada siswa tentang pentingnya pengetahuan biologi untuk kehidupan

13. Pelajaran biologi tidak mengajarkan siswa tentang bagaimana menjaga kesehatan diri sendiri

14. Siswa dapat memahamilingkungan tanpa harus belajar biologi

IS: 60.9]\%

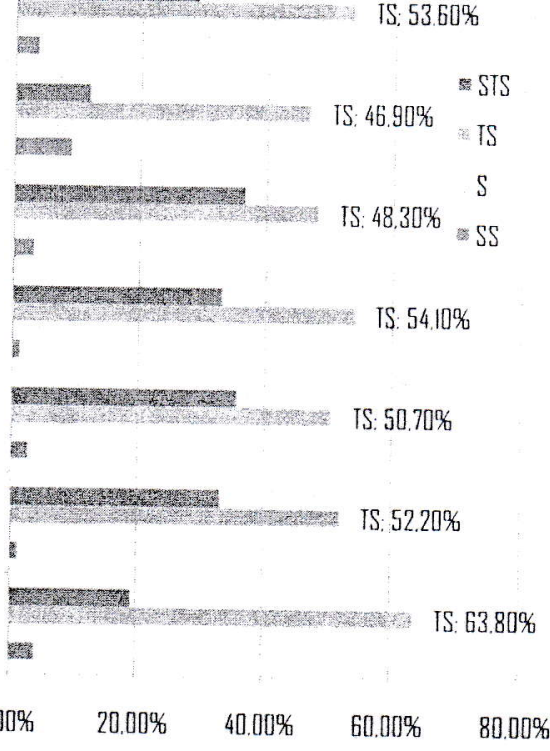

Gambar 3. Sebaran Jawaban Responden Tentang Pentingnya Biologi

Keterangan : SS : Sangat Setuju

$$
\begin{array}{ll}
\text { S } & \text { : Setuju } \\
\text { TS } & \text { : Tidak Setuju } \\
\text { STS } & \text { : Sangat Tidak Setuju }
\end{array}
$$

Berdasarkan Gambar 3, dari 30 mahasiswa, sebagian besar mahasiswa $(50.7 \%-63.8 \%)$ tidak setuju tentang hal-hal yang mahasiswa pelajari melalui pelajaran biologi tidak dapat membantu kehidupan mahasiswa sehari-hari, tidak setuju pelajaran biologi merupakan pelajaran yang tidak penting dibandingkan dengan pelajaran lain, mahasiswa tidak setuju bahwa pelajaran biologi tidak 
memperlihatkan kepada mahasiswa tentang pentingnya pengetahuan biologi untuk kehidupan, mahasiswa tidak setuju bahwa pelajaran biologi tidak mengajarkan mahasiswa tentang bagaimana menjaga kesehatan diri sendiri, mahasiswa tidak setuju jika mahasiswa dapat memahami lingkungan tanpa harus belajar biologi.

Berdasarkan data yang diperoleh, secara umum sebagian besar mahasiswa $(50.7 \%-60.4 \%)$ menganggap pelajaran biologi merupakan pelajaran yang penting karena berkaitan dengan kehidupan sehari-hari, termasuk dapat memahami lingkungan dan mengajarkan mahasiswa untuk menjaga kesehatan diri sendiri.

\section{Pembahasan}

Dalam Kurikulum Tingkat Satuan Pendidikan, terdapat 37 materi biologi yang akan dipelajari oleh mahasiswa selama berada di tingkat SMA. Dari 37 materi tersebut, terdapat 21 materi $(57 \%)$ yang paling diminati mahasiswa untuk dipelajari. Hal ini menunjukkan bahwa sebagian besar materi biologi sangat diminati oleh mahasiswa baru tahun ajaran 2009/2010 di program studi pendidikan biologi FKIP Untan.

Berdasarkan Tabel 2, dari 21 materi yang sangat diminati oleh mahasiswa, hampir seluruhnya (18 materi atau $85.7 \%$ ) merupakan materi yang bersifat konkrit. Sebagian kecil materi ( $14.3 \%$ atau tiga materi) yang memiliki sifat abstrak yaitu materi virus, fungsi enzim dan konsep gen, DNA, kromosom dan proses sintesis protein.

Berdasarkan teori perkembangan kognitif menurut
Piaget, tahap perkembangan mahasiswa berada pada tahap operasional formal. Ciri pokok dalam tahap perkembangan ini adalah anak sudah mampu berpikir abstrak dan logis. Tetapi berdasarkan penelitian maupun studi selanjutnya menemukan banyak mahasiswa walaupun usianya telah melampaui, belum dapat melakukan operasional formal, artinya belum dapat berpikir secara abstrak dan logis (Budiningsih, 2012: 39). Untuk materi yang bersifat abstrak, diperlukan kreatifitas dosen agar dapat mengkonkritkan konsep yang abstrak tadi agar lebih mudah dipahami oleh mahasiswa.

Materi biologi yang sangat diminati oleh mahasiswa berkaitan dengan upaya yang dilakukan oleh hampir seluruh dosen. Pada umumnya $(83.3 \%-100 \%) \quad$ dosen sering melibatkan seluruh mahasiswa dalam pembelajaran; berusaha untuk membantu mahasiswa agar dapat berpikir kritis; mengajarkan konsepkonsep biologi secara efektif; memberikan penjelasan alternatif atau dengan contoh-contoh; menanggapi pertanyaan yang sulit dari mahasiswa; dan mencari cara yang lebih baik untuk mengajarkan konsep-konsep biologi yang terdapat dalam kurikulum.

Berbagai upaya yang dilakukan oleh dosen, baik secara langsung ataupun tidak langsung akan mempengaruhi kondisi minat mahasiswa pada pelajaran biologi. Hal ini terlihat dari pendapat mahasiswa tentang dosen biologi mereka. Hampir sebagian mahasiswa (44.4\%) berpendapat bahwa dosen biologi mereka menguasai setiap materi yang diajarkan dan dapat menyajikannya dengan menarik. Hal 
tersebut sesuai dengan pernyataan NRC, (1996:28) bahwa apa yang dipelajari mahasiswa sangat dipengaruhi oleh cara dosen pada saat mengajar.

Dosen yang efektif akan menciptakan lingkungan yang memungkinkan dosen dan mahasiswa bekerja bersama sebagai pembelajar yang aktif. Sementara mahasiswanya belajar dengan pengalaman langsung dengan sumber belajar. Dosen belajar memahami bagaimana mahasiswa yang berbeda dalam minat, kemampuan dan pengalaman menjadi senang belajar sains. Belajar bagaimana dosen memberikan dukungan dan bimbingan yang efektif pada mahasiswanya sehingga tercipta interaksi edukatif.

Hasil penelitian menunjukkan bahwa secara keseluruhan, skor ratarata minat pada materi biologi di setiap kategori berada pada kategori cukup berminat, dan seluruh indikator dalam minat mahasiswa berada dalam kategori cukup berminat.

Hasil penelitian minat mahasiswa pada materi biologi menunjukkan bahwa hampir sebagian mahasiswa $(42.1 \%)$ sangat berminat pada sebagian besar materi biologi. Hal ini berhubungan dengan manfaat pelajaran biologi yang dirasakan oleh mahasiswa, sebagian besar mahasiswa $(62.3 \%)$ menganggap bahwa pelajaran biologi merupakan pelajaran yang penting karena berkaitan dengan kehidupan seharihari, dapat memahami lingkungan dan dapat mengajarkan untuk menjaga kesehatan diri sendiri, sehingga pada akhirnya timbul minat karena adanya kebutuhan terhadap materi biologi. Hal ini sesuai dengan apa yang dikemukakan oleh Djamarah (2005) bahwa minat timbul berkaitan dengan masalah kebutuhan seseorang. Artinya jika minat yang muncul sesuai dengan kebutuhan maka dapat menjadi faktor pendorong dalam melakukan suatu tindakan, oleh karena itu guru sebaiknya memberikan motivasi dengan memanfaatkan kebutuhan peserta didik agar dia berminat untuk belajar. Faktor kebutuhan akan pelajaran biologi yang muncul dalam diri mahasiswa terlihat dari ungkapan positif tentang pelajaran tersebut. Dalam proses pembelajaran sering terjadi jika peserta didik berminat terhadap materi pelajaran, maka sikap peserta didik cenderung memperhatikan pelajaran tersebut.

Menurut Arifin (2012: 241), minat merupakan salah satu faktor yang dapat mempengaruhi proses dan hasil belajar. Hal tersebut didukung dengan keadaan bahwa sebagian besar mahasiswa $(52.7 \%)$ menyukai pelajaran biologi dan, sebagian besar mahasiswa (51.7\%) menganggap pelajaran biologi merupakan pelajaran yang mudah di pelajari. Sejalan dengan hal tersebut, hasil penelitian Prokop \& Prokop (2007) menunjukkan mahasiswa menganggap bahwa pelajaran biologi adalah pelajaran yang menarik, tidak sulit dan sangat penting bagi kehidupan mereka.

Hampir sebagian mahasiswa (41.1\%) menyatakan dosen biologi mereka selalu menyajikan materi dengan menarik. Hasil penelitian Prokop \& Chuda (2007) memiliki temuan yang sama, bahwa sebagian besar mahasiswa (71\%) memiliki sikap positif terhadap dosen mereka karena dapat menyajikan materi dengan baik. Asumsi yang 
menyatakan bahwa ketertarikan mahasiswa pada suatu mata pelajaran dengan alasan dosennya menarik adalah benar berdasarkan hasil penelitian ini.

Namun diperoleh informasi hampir sebagian mahasiswa $(46.9 \%)$ tidak ingin mendapatkan pelajaran biologi lebih sering. Keadaan tersebut berkaitan dengan faktor kebosanan. Slameto (2010) menyatakan bahwa kebosanan merupakan salah satu faktor internal yang dapat menurunkan minat, karena melakukan aktifitas terus menerus secara monoton akan menimbulkan kebosanan dan hal tersebut dapat menyebabkan menurunnya minat mahasiswa terhadap pembelajaran.

Keadaan hampir sebagian mahasiswa (44.4\%) tidak menyukai dosen biologi karena cara menyampaikan materinya sulit dipahami berkaitan dengan faktor eksternal yang dapat mempengaruhi minat mahasiswa. Slameto (1995: 66) menyatakan bahwa dalam relasi (dosen dengan mahasiswa) yang baik, mahasiswa yang menyukai dosennya akan berusaha mempelajari pelajaran yang disampaikan dengan sebaikbaiknya. Hal tersebut dapat terjadi sebaliknya, jika mahasiswa membenci dosennya, ia segan mempelajari mata pelajaran yang diberikannya, sehingga dapat menurunkan minat mahasiswa pada pembelajaran. Selain itu, rangsangan eksternal lainnya dapat berupa tujuan pembelajaran, dosen yang mengajar, bahan ajar, metode pembelajaran, media pembelajaran, suasana kelas serta lingkungan masyarakat dapat mendukung minat mahasiswa terhadap biologi.

\section{Simpulan}

Sebagian besar $(56.8 \%)$ materi biologi yang terdapat dalam KTSP sangat diminati oleh mahasiswa program studi pendidikan biologi FKIP Untan. Minat mahasiswa program studi pendidikan biologi FKIP Untan pada materi biologi berada dalam kategori cukup berminat.

\section{Daftar Pustaka}

Arifin. Z.(2012). Penelitian Pendidikan Metode dan Paradigma Baru. Bandung: Remaja Rosdakarya.

Budiningsih. A. (2012). Belajar dan Pembelajaran. Jakarta: Rineka Cipta.

Depdiknas. (2008). Pengembangan Perangkat Penilaian Afektif. Jakarta: Depdiknas.

Djamarah, S.B. (2005). Guru dan Anak Didik dalam Interaksi Edukatif. Jakarta: Rineka Cipta.

Ekli, E.. Karadon, H. D \& Sahin, N. (2009). "High Scool Students Attitudes and Opinions Regarding Biology Course and Biological Science". Procedia Social and Behavior Sciences. 1, 1137-1140.

National Reseach Council. (1996). National Science Education Standard. Washington DC: National Academic Press.

Prokop, P., Prokop, M. \& Tunnicliffe, S.D. (2007). "Is Biology Boring? Student Attitudes toward Biologi". Educational Reseach. 42, (1).

Prokop, P., Tuncer, G. \& Chuda, J. (2007). "Slovakian Students' Attitudes toward Biology". Eurasia Journal of Mathematics, Science \& 
36 Jurnal Pendidikan Matematika dan IPA I'ol. 3. No. 2. Juli 20/2:26-36

Technology Education. 3, (4), 287-295.

Riduwan. (2005). Belajar Mudah Penelitian Untuk Guru. Karyawan dan Peneliti Pemula.

Rustaman, N. (2005). Strategi Belajar Mengajar Biologi. Malang: Universitas Negeri Malang (UM Press).

Bandung. Alfabeta. 